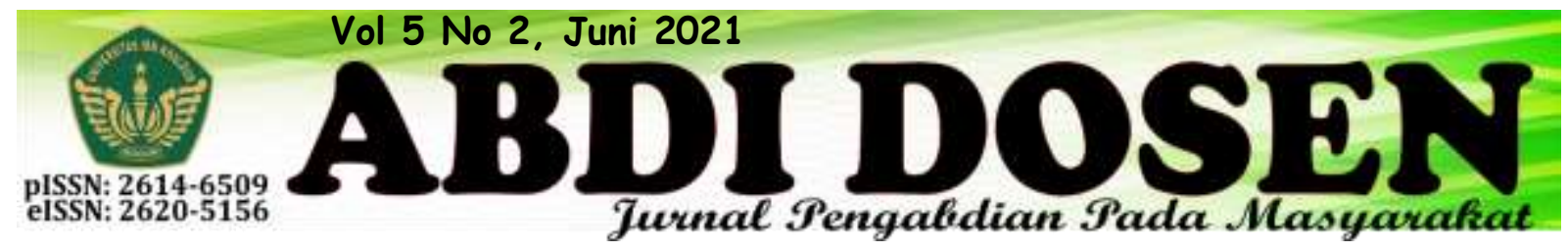

\title{
KOMUNIKASI, INFORMASI DAN EDUKASI (KIE) PEDOMAN GIZI SEIMBANG DALAM MENCEGAH MASALAH GIZI PADA BALITA
}

\author{
Dwi Yulia Maritasari ${ }^{1}$ dan Dian Utama Pratiwi Putri ${ }^{2}$ \\ dwiyulia@umitra.ac.id ${ }^{1}$ \\ dian@umitra.ac.id ${ }^{2}$ \\ Fakultas Kesehatan Universitas Mitra Indonesia ${ }^{1,2}$
}

\begin{abstract}
ABSTRAK
Anak merupakan investasi sumber daya manusia (SDM) yang memerlukan perhatian khusus untuk kecukupan status gizinya sejak lahir, bahkan sejak dalam kandungan. Gizi pada masa balita akan mempengaruhi perkembangan di masa berikutnya. Hasil Pemantauan Status Gizi (PSG) tahun 2017, di Provinsi Lampung sebanyak 15\% balita mengalami gizi kurang, dan $10,10 \%$ balita mengalami stunting. Salah satu upaya yang dapat dilakukan untuk mengatasi masalah gizi pada anak yaitu dengan penerapan gizi seimbang. Tujuan dari pengabdian kepada masyarakat ini adalah untuk memberikan pendidikan kepada ibu yang memiliki balita mengenai pedoman gizi seimbang disertai dengan informasi mengenai piramida makanan dan piring makanku di Desa Toton Katon Punggur Lampung Tengah. Kegiatan pengabdian kepada masyarakat dilakukan di Desa Toton Katon pada saat kegiatan Posyandu yaitu Posyandu Nusa Indah. Sasaran kegiatan pengabdian kepada masyarakat ini adalah Ibu yang memiliki balita. Kegiatan ini diawali dengan penimbangan berat badan dan tinggi badan. Kemudian, Penyuluhan Kesehatan berupa penyampaian informasi secara langsung mengenai pedoman gizi seimbang, pemaparan visual dan slogan tumpeng gizi seimbang dan piring makanku dengan bantuan alat peraga. Setelah penyuluhan dilakukan sesi tanya jawab dan edukasi mengenai pemilihan bahan makanan sehat dan bergizi. Pemberian pengetahuan tentang gizi kepada ibu merupakan strategi dalam meningkatkan status gizi anak. Sehingga harapannya dapat menurunkan kasus status gizi kurang dan stunting yang terjadi pada balita.
\end{abstract}

\section{Kata Kunci : Pedoman Gizi Seimbang, Balita, Gizi Kurang, Stunting}

\section{ABSTRACT}

Children are investments in human resources $(H R)$ that require special attention to the adequacy of nutritional status from birth, even in the womb. Nutrition during infancy will affect development in the future. Results of Nutrition Status Monitoring (PSG) in 2017, in Lampung Province as many as $15 \%$ of children under five experienced malnutrition, and $10.10 \%$ of children under five had stunting. One effort that can be done to overcome the problem of nutrition in children is by applying balanced nutrition. The purpose of this community service is to provide education to mothers who have toddlers regarding balanced nutrition guidelines accompanied by information about the food pyramid and my dinner plate in Toton Katon Punggur Village, Central Lampung. Community service activities are carried out in Toton Katon Village during Posyandu activities, Posyandu Nusa Indah. The target of community service activities is mothers who have toddlers. This activity begins with weighing body weight and height. Then, Health Counseling in the form of delivering information directly on balanced nutrition guidelines, visual exposure and balanced nutrition slogan and my dinner plate with the help of props. After counseling, a question and answer and education session was held regarding the selection of healthy and nutritious food ingredients. Providing knowledge about nutrition to mothers is a strategy in improving children's 
nutritional status. So that the hope can reduce the cases of malnutrition and stunting that occur in infants.

\section{Keywords: Balanced Nutrition Guidelines, Toddler, Nutrition, Stunting}

\section{PENDAHULUAN}

Salah satu ciri bangsa maju adalah bangsa yang memiliki tingkat kesehatan, kecerdasan, dan produktivitas kerja yang tinggi. Ketiga hal ini dipengaruhi oleh keadaan gizi (Kementerian Kesehatan Republik Indonesia, 2014). Anak merupakan investasi sumber daya manusia (SDM) yang memerlukan perhatian khusus untuk kecukupan status gizinya sejak lahir, bahkan sejak dalam kandungan. Balita akan sehat jika sejak awal kehidupannya sudah diberi makanan sehat dan seimbang sehingga kualitas SDM yang dihasilkan optimal (Auliana, 2011). Gizi pada lima tahun pertama kehidupan sangat penting karena pada ini perkembangan fisik dan perkembangan otak paling pesat. Gizi pada masa balita akan mempengaruhi perkembangan di masa berikutnya (Kementrian Kesehatan RI, 2014).

Hasil Pemantauan Status Gizi (PSG) tahun 2017 yang diselenggarakan oleh Kementerian Kesehatan menyatakan bahwa persentase gizi buruk pada balita usia 0-59 bulan di Indonesia adalah 3,8\%, sedangkan persentase gizi kurang adalah 14\%. Hal tersebut tidak berbeda jauh dengan hasil PSG tahun 2016 yaitu persentase gizi buruk pada balita usia 0-59 bulan sebesar 3,4\% dan persentase gizi kurang sebesar $14,43 \%$. Persentase balita sangat pendek dan pendek usia 0-59 bulan di Indonesia tahun 2017 adalah 9,8\% dan $19,8 \%$. Kondisi ini meningkat dari tahun sebelumnya yaitu persentase balita sangat pendek sebesar $8,57 \%$ dan balita pendek sebesar 18,97\% (Profil Kesehatan Indonesia, 2017).
Berdasarkan data Riset Kesehatan Dasar (Riskesdas) tahun 2018 menunjukkan bahwa di Indonesia angka prevalensi kejadian gizi kurang pada anak balita sebesar 13,8 \% dan angka kejadian gizi buruk sebesar 3,9 \%. Sedangkan sebanyak 19,3 \% balita dikategorikan pendek, dan sebesar 11,5 \% balita dikategorikan sangat pendek (Riskesdas, 2018). Pada tahun 2016 di Provinsi Lampung sebanyak $12,36 \%$ balita mengalami gizi kurang berdasarkan indeks $\mathrm{BB} / \mathrm{U}$, meningkat menjadi $15 \%$ balita di tahun 2017. Berdasarkan Indeks TB/U diketahui bahwa di Provinsi Lampung pada tahun 2016 sebanyak 6,59\% anak mengalami stunting meningkat menjadi 10,10\% balita di tahun 2017 (Profil Kesehatan Indonesia, 2017).

Salah satu upaya yang dapat dilakukan untuk mengatasi masalah gizi pada anak yaitu dengan penerapan gizi seimbang. Gizi seimbang merupakan Susunan pangan sehari-hari yang mengandung zat gizi dalam jenis dan jumlah yang sesuai dengan kebutuhan tubuh, dengan memperhatikan prinsip keanekaragaman pangan, aktivitas fisik, perilaku hidup bersih dan mempertahankan berat badan normal untuk mencegah masalah gizi (Kementerian Kesehatan Republik Indonesia, 2014).

Pola asuh anak telah diidentifikasi sebagai faktor dalam praktik pemberian makanan pada anak-anak. Dalam upaya memenuhi pedoman gizi seimbang, edukasi ibu harus menjadi fokus utama dalam intervensi gizi (Slusser et al., 2011). 
Pendidikan ibu mengenai pedoman gizi seimbang mempunyai peranan penting dalam menentukan status gizi balita. Peningkatan pendidikan ibu akan meningkatkan status gizi balita yang pada akhirnya dapat meningkatkan peluang kesempatan pendidikan balitanya sebagai modal dasar peningkatan sumber daya manusia yang berkualitas (Damanik, Ekayanti, \& Hariyadi, 2017).

Pada tahun 2014, Direktorat Bina

Gisi Kementerian Kesehatan RI mengeluarkan Buku Pedoman Gizi Seimbang yang bertujuan untu menyediakan pedoman makanan dan pesilaku sehat bagi seluruh lapisan masyarakat berdasarkan prinsip anekaragam pangan, aktivitas fisik, hidup bersih, dan mempertahankan berat badan normal. Untuk mengoptimalkan penyampaian pesan-pesan gizi seimbang pada masyarakat, diperlukan KIE yang tepat dan berbasis masyarakat, sehingga dapat mencegah timbulnya masalah gizi (Kementerian Kesehatan Republik Indonesia, 2014)

Permasalahan yang ditemukan dalam menghambat penerapan gizi seimbang yaitu masyarakat tidak mengikuti praktikpraktik pemilihan dan pengolahan makanan yang sehat, Posyandu dipandang baik namun tidak lagi cukup up-to-date untuk masyarakat sehingga masyarakat cenderung mengabaikan keberadaan Posyandu, latar belakang budaya termasuk kepercayaan terhadap makanan dan pemaknaan tentang makanan sangat berpengaruh terhadap pemilihan makanan,

\section{METODE PELAKSANAAN}

Kegiatan pengabdian kepada masyarakat dilakukan di Desa Toton Katon pada saat kegiatan Posyandu yaitu Posyandu Nusa Indah. Sasaran kegiatan strategi pembangunan Pedoman Gizi Seimbang (PGS) belum melibatkan unsurunsur masyarakat seperti guru, murid sekolah, ibu balita, pemimpin lokal dan kader atau petugas kesehatan itu sendiri (Koesbardiati, 2012).

Desa Toton Katon merupakan salah satu desa yang berada di Wilayah Kerja Puskesmas Punggur Kabupaten Lampung Tengah. Kabupaten menargetkan jumlah kasus maksimal balita gizi kurang $<15 \%$ balita. Berdasarkan laporan SKDN, jumlah balita yang naik timbangannya sebesar $62,8 \%$. Jumlah ini belum mencapai target sebesar $90 \%$. Kegiatan pengabdian kepada masyarakat ini memiliki target luaran yang ingin dicapai adalah peningkatan pengetahuan ibu mengenai gizi seimbang sehingga ibu mampu memilih makanan yang tepat untuk anaknya. Selain itu hasil pengabdian kegiatan pengabdian kepada masyakat ini menghasilkan gambaran status gizi anak balita di Desa Toton Katon sehingga daopat dijadikan dasar untuk menyusun program kerja dalam mengatasi masalah gizi yang terjadi di Desa tersebut.

Oleh karena itu perlunya komunikasi, informasi, dan edukasi mengenai pedoman gizi seimbang untuk meningkatkan status gizi balita di Desan Toton Katon. Tujuan dari pengabdian kepada masyarakat ini adalah untuk memberikan pendidikan kepada ibu yang memiliki balita mengenai pedoman gizi seimbang disertai dengan informasi mengenai piramida makanan dan piring makanku di Desa Toton Katon Punggur Lampung Tengah.

pengabdian kepada masyarakat ini adalah Ibu yang memiliki balita. Pola asuh anak telah diidentifikasi sebagai faktor dalam praktik pemberian makanan pada anak- 
anak. Dalam upaya memenuhi pedoman gizi seimbang, ibu harus menjadi fokus utama dalam intervensi gizi.

Metode kegiatan pengabdian kepada masyarakat ini dilakukan dengan langkah sebagai berikut.

1. Pengukuran tinggi badan, berat badan balita. Pengukuran berat badan dan tinggi badan ini dimaksudkan untuk mengetahi status gizi dari balita. Kemudian dilakukan penentuan status gizi berdasarkan Indeks $\mathrm{BB} / \mathrm{U}$ dan TB/U.

2. Penyuluhan Kesehatan berupa penyampaian informasi secara langsung mengenai 4 Pilar Gizi Seimbang, 10 Pesan Umum Gizi Seimbang, Pesan Gizi Seimbang untuk Balita. Kemudian dilanjutkan dengan pemaparan slogan dan visual gizi seimbang (Tumpeng Gizi Seimbang dan Piring Makanku). Penyampaian materi menggunakan metode ceramah dengan alat bantu berupa poster yang berisi informasi mengenai pilar gizi

\section{HASIL DAN PEMBAHASAN}

Kegiatan pengabdian kepada masyarakat ini diawali dengan pengukuran berat badan dan tinggi badan balita yang kemudian ditentukan dilakukan penilaian status gizi secara antropometri berdasarkan indeks $\mathrm{BB} / \mathrm{U}$ dan $\mathrm{TB} / \mathrm{U}$ untuk mengetahui jumlah balita yang mengalami gizi kurang dan stunting. Balita yang dikategorikan gizi kurang jika nilai Z-Score <- 2 SD seimbang, dan pesan gizi seimbang. Informasi mengenai Slogan dan Visual Gizi menggunakan Media Alat Peraga yang merupakan bentuk replika sesuai dengan Gambar Tumpeng Gizi Seimbang dan Piring Makanku.

Setelah proses penyuluhan, dilanjutkan dengan tanya jawab dan edukasi mengenai contoh-contoh menu sehat dan bergizi dari bahan makanan setempat yang sesuai dengan prinsip gizi seimbang. Kegiatan ini mendapat sambutan yang positif dan ibu sangat antusias dalam mendapatkan informasi mengenai menu makanan yang sehat dan bergizi.

Evaluasi yang dilakukan adalah dengan memberikan pertanyaanpertanyaan ke ibu-ibu mengenai materi yang disampaikan sebelumnya. Rencana pengabdian kepada masyarakat lanjutan adalah meningkatkan keterampilan ibu-ibu dalam menyusun menu sehari-hari dengan menerapkan pedoman gizi seimbang.

berdasarkan indeks $\mathrm{BB} / \mathrm{U}$, sedangkan balita yang dikategorikan stunting jika nilai Z-Score berdasarkan indeks TB/U (Kementerian Kesehatan Republik Indonesia, 2010). Tabel 1.1 merupakan hasil penilaian status gizi pada balita di Desa Toton Katon Punggur Lampung Tengah.

Tabe1 1 Hasil Penilaian Status Gizi Balita

\begin{tabular}{|c|c|c|}
\hline Kategori & $\begin{array}{l}\text { Jumlah } \\
(n=24)\end{array}$ & Persentase \\
\hline \multicolumn{3}{|c|}{ Berdasarkan Indeks BB/U } \\
\hline $\begin{array}{l}\text { Gizi Kurang } \\
\text { (-3 SD s.d -2 SD) }\end{array}$ & 9 & $37,5 \%$ \\
\hline $\begin{array}{l}\text { Normal } \\
(-2 \text { SD s.d } 2 \text { SD) }\end{array}$ & 13 & $54,2 \%$ \\
\hline Gizi Lebih & 2 & $8,3 \%$ \\
\hline
\end{tabular}




\begin{tabular}{|l|c|c|}
\hline (>2 SD) & \multicolumn{2}{|l|}{} \\
\hline Berdasarkan Indeks TB/U & \multicolumn{2}{|l|}{} \\
\hline $\begin{array}{l}\text { Pendek } \\
(-3 S D \text { s.d. }<-2 \text { SD) }\end{array}$ & $83,3 \%$ \\
\hline $\begin{array}{l}\text { Normal } \\
(-2 \text { SD s.d. 2 SD) }\end{array}$ & 13 & $66,7 \%$ \\
\hline
\end{tabular}

Sumber : Posyandu Nusa Indah, 2019

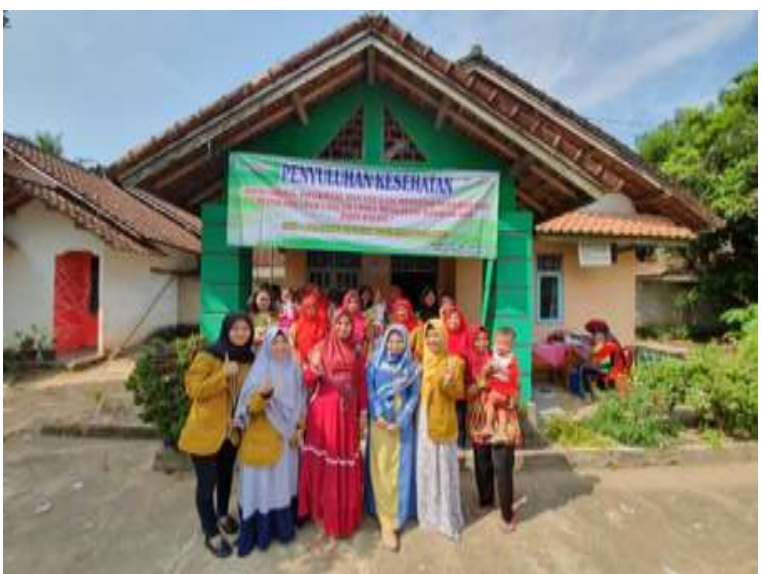

Gambar 1.1. Kegiatan Penyuluhan Posyandu Nusa Indah

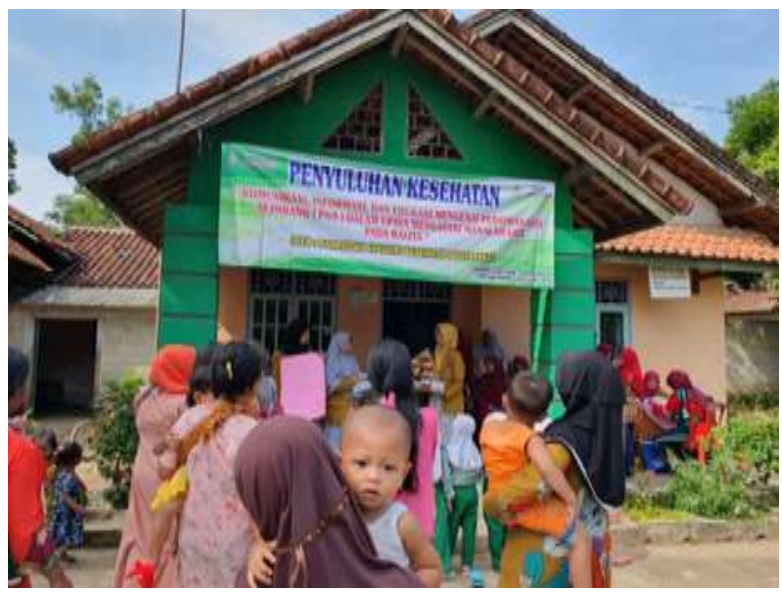

Gambar1.2. Pemaparan Visual dan Slogan Pesan Gizi Seimbang

Desa Toton Katon

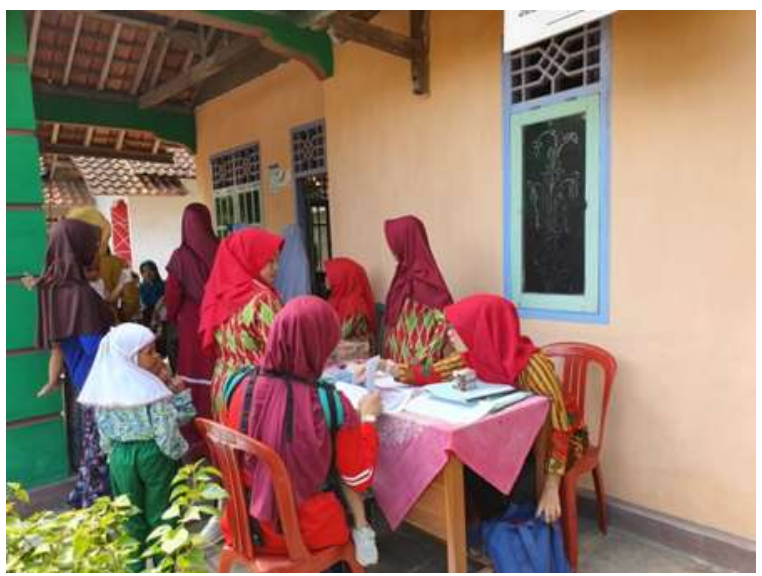

Gambar 1.3. Pengumpulan Data Status Gizi Posyandu Nusa Indah

Sampai saat ini gizi masih menjadi masalah di negara berkembang maupun negara maju. Salah satu cara untuk menanggulangi masalah gizi adalah dengan melaksanakan program KIE gizi. KIE gizi adalah suatu cara pemberian informasi atau pesan yang berkaitan dengan gizi dari seseorang atau masyarakat sebagai penerima pesan melalui media tertentu. Tujuan akhir dari
KIE adalah adanya perubahan kebiasaan perilaku dari yang tidak mendukung menjadi mendukung terhadap peningkatan status gizi (Departemen Gizi dan Kesehatan Masyarakat Universitas Indonesia, 2014).

Penyuluhan dilakukan kepada ibu yang memiliki balita untuk memberikan pendidikan mengenai gizi seimbang. Penyuluhan mengenai gizi seimbang 
berlangsung dengan baik dan lancar. Peserta penyuluhan terdiri dari ibu yang memiliki balita yang berjumlah 24 orang. Informasi yang diberikan meliputi pilar gizi seimbang, pesan umum gizi seimbang, pesan khusus gizi seimbang untuk balita. Gizi seimbang merupakan Susunan pangan sehari-hari yang mengandung zat gizi dalam jenis dan jumlah yang sesuai dengan kebutuhan tubuh, dengan memperhatikan prinsip keanekaragaman pangan, aktivitas fisik, perilaku hidup bersih dan mempertahankan berat badan normal untuk mencegah masalah gizi (Kementerian Kesehatan Republik Indonesia, 2014). Terlihat bahwa ibu-ibu memiliki antusiasme yang tinggi saat diberikan informasi mengenai gizi seimbang untuk anak.

Pedoman Gizi Seimbang (PGS) bertujuan untuk menyediakan pedoman makan dan berperilaku sehat bagi seluruh lapisan masyarakat berdasarkan prinsip konsumsi anekaragam pangan, perilaku hidup bersih, aktivitas fisik dan mempertahankan berat badan normal. Prinsip gizi seimbang terdiri dari 4 (empat) pilar yang pada dasarnya merupakan rangkaian upaya untuk menyeimbangkan antara zat gizi yang keluar dan zat gizi yang masuk dengan memonitor berat badan yang ideal secara teratur. Empat pilar itu meliputi mengkonsumsi pangan beranekaragam, membiasakan perilaku hidup bersih, melakukan aktivitas fisik, dan mempertahankan dan memantau berat badan normal (Kementerian Kesehatan Republik Indonesia, 2014).

Pengetahuan dasar tentang gizi yang dimiliki oleh ibu membantu dalam memilih dan membeli makanan yang tepat untuk anaknya. Sebagian besar ibu memahami pengetahuan dasar tentang makanan sehat menunjukkan minat dan kepedulian tentang nutrisi yang kaitannya dengan kesehatan. Mereka akan mempertimbangkan kesehatan anakanaknya saat berbelanja bahan makanan dan mempersiapkan makanan untuk keluarga. Mereka akan mencoba memilh makanan yang bergizi dan mencari cara untuk menyiapkan makanan secara lebih sehat untuk keluarga (Slusser et al., 2011).

Pada saat penyuluhan, ibu-ibu dianjurkan untuk menerapkan pesan gizi seimbang dalam menyiapkan makanan dan mengatur pola makan untuk keluarga. Pesan gizi seimbang meliputi syukuri dan nikmati anekaragam makanan, banyak sayuran dan cukup buah-buahan, biasakan mengkonsumsi lauk pauk yang mengandung protein tinggi, biasakan mengkonsumsi anekaragam makanan pokok, batasi konsumsi pangan manis, asin, dan berlemak, biasakan sarapan, biasakan minum air putih yang cukup dan aman, biasakan membaca label pada kemasan pangan, cuci tangan pakai sabun dengan air bersih yang mengalir, serta lakukan aktifitas fisik yang cukup untuk mempertahankan berat badan normal (Kementerian Kesehatan Republik Indonesia, 2014)

Pada saat sesi tanya jawab didapatkan informasi bahwa hambatan dari seorang ibu dalam membangun kebiasaan makanan yang sehat untuk keluarga adalah biaya, serta kesulitan dalam membuat anak-anak mereka untuk mengkonsumsi makanan sehat, dan akses mudah dalam mengkonsumsi makanan cepat saji. Akan tetapi bahan makanan yang bergizi tidak selalu yang memiliki harga yang tinggi. Pada saat memberikan edukasi mengenai contoh-contoh menu sehat dan bergizi, lebih ditekankan pada penggunaan bahan pangan lokal sebagai bahan pengganti yang memiliki kandungan dan nilai gizi yang 
sama. Ibu-ibu sangat antusias dalam mendiskusikan menu-menu makanan bergizi yang dapat dikonsumsi di keluarga.

Terlihat pada saat penyuluhan antusias ibu-ibu sangat tinggi saat membicarakan sesuatu yang ada kaitannya dengan makanan. Hasil penelitian menunjukkan bahwa sebagian besar ibu bersedia untuk mengikuti kelas gizi,

\section{KESIMPULAN DAN SARAN}

Hasil pemantauan status gizi yang dilakukan di Desa Toton Katon menunjukkan bahwa sebanyak 37,5\% balita mengalami gizi kurang, dan 33,3\% balita mengalami stunting. Pola asuh anak telah diidentifikasi sebagai faktor dalam praktik pemberian makanan pada anakanak. Dalam upaya memenuhi pedoman gizi seimbang, ibu harus menjadi fokus utama dalam intervensi gizi.

Penyuluhan dilakukan kepada ibu yang memiliki balita untuk memberikan

\section{DAFTAR PUSTAKA}

Auliana, R. (2011). Gizi seimbang dan makanan sehat untuk anak usia dini. Yogyakarta: Universitas Negeri Yogyakarta.

Damanik, M. R., Ekayanti, I., \& Hariyadi, D. (2017). Analisis Pengaruh Pendidikan Ibu Terhadap Status Gizi Balita Di Provinsi Kalimantan Barat. Jurnal Gizi Dan Pangan. https://doi.org/10.25182/jgp.2010.5.2. 69-77

\section{Departemen Gizi dan Kesehatan Masyarakat Universitas Indonesia. (2014). Gizi dan Kesehatan Masyarakat. In RajaGrafindo Persada. https://doi.org/10.1017/CBO9781107}

mereka menyatakan keinginannya untuk mengikuti kelas gizi, karena hal tersebut adalah cara yang efektif untuk meningkatkan status gizi seluruh keluarga. Mendukung ibu dalam mendapatkan pendidikan mengenai gizi seimbang merupakan strategi penting dalam meningkatkan status gizi anak (Slusser et al., 2011).

pendidikan mengenai gizi seimbang. Informasi yang diberikan meliputi pilar gizi seimbang, pesan umum gizi seimbang, pesan khusus gizi seimbang untuk balita. Pemberian pengetahuan tentang gizi kepada ibu merupakan strategi dalam meningkatkan status gizi anak. Sehingga harapannya dapat menurunkan kasus status gizi kurang dan stunting yang terjadi pada balita.

\section{$\underline{415324.004}$}

Kementerian Kesehatan Republik Indonesia. (2010). Keputusan Menteri Kesehatan Republik Indonesia Nomor 1995/MENKES/SK/XII/2010 tentang Standar Antropometri Penilaian Status Gizi Anak. Kementerian Kesehatan RI.

$$
\begin{gathered}
\text { Kementerian Kesehatan Republik } \\
\text { Indonesia. (2014). Pedoman Gizi } \\
\text { Seimbang Permenkes RI. Pedoman } \\
\text { Gizi Seimbang Permenkes RI. } \\
\text { https://doi.org/10.1007/s13398-014- } \\
\underline{0173-7.2}
\end{gathered}
$$

Kementrian Kesehatan RI. (2014). Situasi Gizi. Infodatin - Pusat Data Dan 
Informasi Kementrian Kesehatan Ri. https://doi.org/10.7503/cjcu20131296

Koesbardiati, T. (2012). Membangun Pedoman Gizi Seimbang (PGS) pada Anak Gizi Buruk di Perkotaan melalui Pendekatan Bio-sosio-kultural. BioKultur, 3(1).

Profil Kesehatan Indonesia 2017. (2017). Data dan Informasi Kesehatan Indonesia. Profil Kesehatan Indonesia. https://doi.org/10.1017/CBO9781107 $\underline{415324.004}$
Riskesdas. (2018). Hasil Utama Riskesdas 2018. In Kementrian Kesehatan Republik Indonesia. https://doi.org/ $\underline{1 \text { Desember } 2013}$

Slusser, W., Prelip, M., Kinsler, J., Erausquin, J. T., Thai, C., \& Neumann, C. (2011). Challenges to parent nutrition education: A qualitative study of parents of urban children attending low-income schools. Public Health Nutrition. https://doi.org/10.1017/S1368980011 000620 